\title{
Cheese Whey Fermentation by Its Native Microbiota: Proteolysis and Bioactive Peptides Release with ACE-Inhibitory Activity
}

\author{
Miguel A. Mazorra-Manzano ${ }^{1, * \mathbb{D}}$, Glen R. Robles-Porchas ${ }^{1}$, Daniel A. González-Velázquez ${ }^{1}$, \\ María J. Torres-Llanez ${ }^{1}$, Marcel Martínez-Porchas ${ }^{2}$ (D) Celia O. García-Sifuentes ${ }^{3}$, \\ Aarón F. González-Córdova ${ }^{1}$ and Belinda Vallejo-Córdoba ${ }^{1}$ \\ 1 Laboratorio de Química y Biotecnología de Productos Lácteos, Coordinación de Tecnología en Alimentos de \\ Origen Animal, Centro de Investigación en Alimentación y Desarrollo, A.C. (CIAD), Carretera, Gustavo \\ Enrique Astiazarán Rosas, No. 46 Col. La Victoria, C.P. 83304 Hermosillo, Sonora, Mexico; \\ glen.robles@estudiantes.ciad.mx (G.R.R.-P.); daniel_nieto_18@hotmail.com (D.A.G.-V.); \\ mtorres@ciad.mx (M.J.T.-L.); aaronglz@ciad.mx (A.F.G.-C.); vallejo@ciad.mx (B.V.-C.) \\ 2 Laboratorio de Biología Experimental, Coordinación de Tecnología en Alimentos de Origen Animal, Centro \\ de Investigación en Alimentación y Desarrollo, A.C., C.P. 83304 Hermosillo, Sonora, Mexico; marcel@ciad.mx \\ 3 Laboratorio de Bioquímica y Calidad de Productos Pesqueros, Coordinación de Tecnología en Alimentos de \\ Origen Animal, Centro de Investigación en Alimentación y Desarrollo, A.C., C.P. 83304 Hermosillo, Sonora, \\ Mexico; sifuentes@ciad.mx \\ * Correspondence: mazorra@ciad.mx
}

Received: 12 November 2019; Accepted: 6 December 2019; Published: 31 January 2020

check for updates

\begin{abstract}
Cheese whey contains about $20 \%$ of the total milk protein and has high nutritional and technological value, as well as attractive biological properties. Whey protein represents an important source of bioactive peptides with beneficial effects on health (e.g., antioxidant, antidiabetic, antihypertensive, etc.). Microbiota in cheese whey can hydrolyze proteins and generate bioactive peptides through a fermentation process. The objective of this study was to evaluate the effect of temperature on the fermentation of cheese whey by its native microbiota, and the action of microbial proteolytic activity on whey proteins to release peptides with inhibitory activity of the angiotensin-converting enzyme (ACE). Whey proteins hydrolysis occurred at all incubation temperatures evaluated $\left(32-50{ }^{\circ} \mathrm{C}\right)$, with the major proteolytic effect within the range of $35-42{ }^{\circ} \mathrm{C}$. Minor whey proteins (i.e., Lf, bovine serum albumin (BSA), and IgG) were more susceptible to degradation, while $\beta$-lactoglobulin and $\alpha$-lactalbumin showed major resistance to microbial proteolytic action. Alfa-amino groups increased from 36 to $360-456 \mu \mathrm{g}$ Gly/mL after $120 \mathrm{~h}$ of fermentation. A higher lactic acid production (11.32-13.55 g/L) and lower $\mathrm{pH}(3.3-3.5)$ were also observed in the same temperature range $\left(32-42{ }^{\circ} \mathrm{C}\right)$. In addition, ACE-inhibitory activity increased from $22 \%$ (unfermented whey) to $60-70 \%$ after $120 \mathrm{~h}$ of fermentation. These results suggest that the fermentation of cheese whey by its native microbiota represents an attractive process to give value to whey for the production of whey-based beverages or functional foods with potential antihypertensive properties.
\end{abstract}

Keywords: cheese whey; whey fermentation; peptides; antihypertensive activity; proteolysis

\section{Introduction}

Cheese whey is the remaining liquid of milk that has been curdled and transformed into cheese. World cheese production increased by 2\% annually and reached around 22 million MT in 2015. This sector produces more whey than any other dairy industry; herein, approximately 8-9 L of whey is generated per $\mathrm{Kg}$ of cheese produced, globally estimated at 180-190 million ton/year [1]. In modern 
cheese factories with advanced technology, whey represents a source of valuable co-products (e.g., whey powder, protein concentrates, isolates, and lactose) that have multiples applications in the food, nutrition, pharmaceutical, and other industries. It is estimated that around $50 \%$ of the whey produced worldwide is recovered and transformed into these products. However, in Latin American countries most of the cheese industry is considered a low-tech or artisanal industry, where whey is traditionally considered a product of "low economic value", discarding daily a large volume of whey to the environment without prior treatment. This practice is considered unacceptable from economical, ecological, and nutritional perspectives, considering that whey retains about $55 \%$ of the original nutrients of milk (e.g., lactose, protein, minerals, and fat), which could be recovered or converted into valuable compounds by diverse bio/technological processes [2,3].

Artisanal cheese production commonly uses raw milk, representing a rich source of lactic acid bacteria (LAB) and other microorganisms that provide attractive and authentic sensorial characteristics to cheese by a fermentative process during cheesemaking or ripening [4]. Hence, whey generated from cheese production using raw milk represents a diverse and rich source of microorganisms that cause its fermentation or decomposition if it is not treated or processed immediately. Also, cheese whey contains between $0.6 \%$ and $1 \%$ of high-nutritional value proteins that are also functionally and biologically attractive, and their hydrolysates represent a rich source of bioactive peptides with antioxidant, antimicrobial, immunomodulatory, and antihypertensive properties. Bioactive peptides production represents an attractive option to add value to whey in the production of functional foods $[2,5,6]$.

Naturally fermented acid whey (NFAW) is obtained by the fermentation of whey using its native microbiota, and it is traditionally used for milk coagulation during the manufacture of some artisanal Mexican cheeses, especially those of pasta-filata type cheeses (e.g., Oaxaca and Asadero). The production of NFAW in artisanal cheese factories is performed without time and temperature control, usually for $1-3$ days of fermentation at environmental temperature $\left(20-40^{\circ} \mathrm{C}\right)$. Therefore, the $\mathrm{pH}$ and lactic acid content are variable; thus, the volume required to be added to milk to reach the acidity required to produce this type of cheeses is uncertain [7]. Spontaneous whey fermentation mostly depends on lactic acid bacteria (LAB), which convert lactose (the major component of whey) into lactic acid. Changes in $\mathrm{pH}$ and lactic acid production by native microbiota in whey to produce NFAW have not been fully addressed, and the changes associated with whey protein degradation during spontaneous whey fermentation are also unknown. Protein hydrolysis can occur through the action of endogenous or exogenous proteolytic enzymes [8], or through fermentation processes with the use of specific bacteria $[9,10]$. Native microbiota can also exert, under adequate fermentation conditions, a hydrolytic effect on whey proteins and release bioactive peptides. Therefore, the objective of this study was to evaluate the effect of temperature on the spontaneous fermentation of whey for lactic acid production (using its endogenous microbiota) and evaluate the proteolytic changes associated with the release of peptides with inhibitory activity of the angiotensin-converting enzyme (ACE) in fermented cheese whey.

\section{Materials and Methods}

\subsection{Chemicals}

Sodium dodecyl sulfate (SDS), glycine, acrylamide, $N, N^{\prime}$-methylene-bis-acrylamide, 2-mercaptoethanol, SDS-PAGE molecular weight marker, and Coomassie brilliant blue R-250 were purchased from Bio-Rad (Hercules, CA, USA). Hippuryl-histidyl-leucine (HHL), sodium metaborate, angiotensin I-converting enzyme (ACE), 2,4,6-trinitrobenzene sulphonic acid (TNBS), trichloroacetic acid (TCA), and other chemicals (all analytical grade) were from Sigma (Sigma-Aldrich Co., St. Louis, $\mathrm{MO}, \mathrm{USA})$. 


\subsection{Materials}

Whey from queso fresco cheese production (using non-pasteurized milk) was obtained from an artisanal cheese factory at La Victoria, Hermosillo, Sonora, Mexico. Whey was cooled on ice and transported to the laboratories at Centro de Investigación en Alimentación y Desarrollo, AC (CIAD) within less than $2 \mathrm{~h}$ after the whey was drained from cheese curd. Samples were used immediately in fermentation experiments. Portions of samples $(200 \mathrm{~mL})$ were kept frozen $\left(-20^{\circ} \mathrm{C}\right)$ for further proximal composition analysis.

\subsection{Lactic Acid Fermentation of Whey}

Samples of fresh whey $(40 \mathrm{~mL})$ were placed in sterile Falcon tubes and incubated in triplicate at 32 , $37,40,42,45$, and $50^{\circ} \mathrm{C}$ for $0,12,24,48,60,72,96$, and $120 \mathrm{~h}$. After fermentation time, samples were cooled and kept frozen $\left(-20^{\circ} \mathrm{C}\right)$ until further analyses. The fermentation experiment was repeated two times.

\subsection{Physicochemical Analysis}

Whey samples were analyzed for their protein content (micro-Kjeldahl method), ash, total solids, $\mathrm{pH}$, and titratable acidity (\% lactic acid), according to the methodology established by the Association of Official Analytical Chemists, AOAC (2002) [11].

\subsection{Proteolysis Evaluation}

Proteolysis occurring during whey fermentation was evaluated by the quantification of free amino groups $\left(\mathrm{NH}_{3}\right)$ by the OPA method (o-phthalaldehyde) following the procedure described by Church et al. (1983) [12]. Briefly, the procedure consisted of mixing $30 \mu \mathrm{L}$ of whey with $600 \mu \mathrm{L}$ of OPA reagent (sodium tetraborate, sodium dodecyl sulfate (SDS)), phthalaldehyde (previously dissolved in methanol), and $\beta-2$ mercaptoethanol) in a 700- $\mu \mathrm{L}$ quartz cell, and the absorbance was recorded at $340 \mathrm{~nm}$. Proteolysis was expressed as the amount $(\mu \mathrm{g})$ of glycine (Gly) released per $\mathrm{mL}$ using a standard curve of Gly.

\subsection{SDS-PAGE Analysis}

Whey samples were analyzed by SDS-PAGE according to the Laemmli's method (1970) [13] using a 15\% polyacrylamide separation gel under reducing conditions with a Mini-PROTEAN III system (BioRad, Richmond, CA, USA). Running conditions were set at $20 \mathrm{~V}$ for $20 \mathrm{~min}$ followed by $120 \mathrm{~V}$ for $2 \mathrm{~h}$. After the staining procedure with Coomassie blue R-250 $(0.25 \% \mathrm{w} / \mathrm{v})$ in water:methanol:acetic acid (45:45:10 ratio) and distaining in water:methanol:acetic acid (45:45:10 ratio) solutions, gels were photodocumented and analyzed using the ChemiDoc XRS system and the Image Lab software (Bio-Rad Laboratories, Inc.).

\subsection{ACE-Inhibitory Activity Assay}

Whey samples were pre-treated by ultrafiltration (UF; $10 \mathrm{KDa}$ Amicon membrane), $\mathrm{pH}$ adjustment (7.5-8.5), and filtered through a $0.22-\mu \mathrm{m}$ syringe filter and kept frozen $\left(-20^{\circ} \mathrm{C}\right)$ until the inhibition assay. ACE-inhibitory activity of the UF peptide fraction $<10 \mathrm{kDa}$ was determined based on the method described by Cushman and Cheung (1971) [14] with some modifications for the analysis of the enzymatic reaction products by HPLC as described by Wu et al. (2002) [15]. Briefly, the substrate solution of $5 \mathrm{mM}$ hippuryl-histidyl-leucine (HHL) in $0.1 \mathrm{M}$ sodium metaborate (pH 8.3, with $0.3 \mathrm{M}$ $\mathrm{NaCl}$ ) and $\mathrm{ACE}$ enzyme solution at $2 \mathrm{mU} / \mathrm{mL}$ were tempered at $37^{\circ} \mathrm{C}$ for $10 \mathrm{~min}$ before mixing. The enzymatic reaction was performed by mixing $50 \mu \mathrm{L}$ of HHL solution with $10 \mu \mathrm{L}$ of ACE and $10 \mu \mathrm{L}$ of borate buffer; the borate buffer was substituted by the inhibition solution (peptide fraction $<10 \mathrm{kDa}$, prepared as described above). A mixture of $50 \mu \mathrm{L}$ of HHL with $20 \mu \mathrm{L}$ of borate buffer was used as blank. Mixtures were vortexed and incubated at $37{ }^{\circ} \mathrm{C}$ with agitation using an Eppendorf Thermomixer at 
$450 \mathrm{rpm}$ for $30 \mathrm{~min}$. The reaction was stopped by the addition of $85 \mu \mathrm{L}$ of $1 \mathrm{M} \mathrm{HCl}$ solution, vortexed, and analyzed by HPLC. The substrate (HHL) and the product of the enzymatic reaction (hippuric acid, HA) were determined using a ZORBAX Eclipse Plus C18 (4.6 × $100 \mathrm{~mm}, 3.5 \mu \mathrm{m})$ column in an Agilent 1260 HPLC system (Agilent Technologies, Waldbronn, Germany) equipped with OpenLAB Chromatography Data System (CDS) version A.02.02 (Agilent Technologies, Germany). Solvent A was water and solvent $\mathrm{B}$ was acetonitrile, with both containing $0.05 \%$ triflouroacetic acid (TFA). A gradient elution from $5 \%$ to $60 \%$ (solvent B) during $10 \mathrm{~min}$ was used. After $2 \mathrm{~min}$ at $60 \%$ solvent $\mathrm{B}$, the gradient was inverted again to $5 \%$ solvent B in $1 \mathrm{~min}$ and kept at $5 \%$ solvent B for $4 \mathrm{~min}$ before the next sample injection. The flow rate was adjusted to $0.5 \mathrm{~mL} / \mathrm{min}$ for a sample injection of $10 \mu \mathrm{L}$ and detection at $228 \mathrm{~nm}$. Samples were analyzed in duplicate with double injection. The percent of the ACE-inhibitory activity was calculated using the following equation:

$$
\% \text { ACE-inhibitory activity }=(\mathrm{A}-\mathrm{B}) / \mathrm{B} \times 100
$$

where $\mathrm{A}$ is the peak area of the hippuric acid (HA) as result of the ACE reaction with the substrate HHL, and $B$ is the peak area of HA after the ACE reaction with substrate HHL in the presence of inhibitor.

\subsection{Statistical Analysis}

Data were subjected to analysis of variance for a one-factor completely randomized design and Tukey's multiple range tests using GraphPad Prism 5, 2017 (GraphPad Software, San Diego, CA, USA) procedure using a significance level of 0.05 .

\section{Results}

\subsection{Temperature Effect on Spontaneous Lactic Acid Whey Fermentation}

Whey from queso fresco production was used in this study and had a $\mathrm{pH}$ close to neutral (6.49-6.56), which is characteristic of a sweet whey $(\mathrm{pH}>6.0)$ [16]. The average content of lactose, ash, protein, and non-protein nitrogen was $4.8 \%, 0.51 \%, 0.72 \%$, and $0.08 \%$, respectively. These characteristics are comparable to those previously reported for sweet whey $[17,18]$.

The biotechnological process has been considered as an attractive option to add value to whey and convert lactose into value-added chemicals such as lactic acid and other compounds, including ethanol, citric, acetic, lactulose, etc., and for developing functional whey-based drinks [2,19]. Endogenous lactic acid bacteria in whey have been scarcely characterized; however, genuses such as Lactococcus, Lactobacillus, and Streptococcus are commonly present and have been associated with lactic acid fermentation. The presence of psychrophilic, mesophilic, and thermophilic bacteria in whey is highly dependent on the environmental temperatures of milking and cheese processing areas and determine the fermentation of whey. The effect of temperature on whey fermentation was monitored by $\mathrm{pH}$ changes and lactic acid production. It was observed that $\mathrm{pH}$ had a rapid shift (from $\mathrm{pH} 6.4$ to $\mathrm{pH}<5$ ) during the first $12 \mathrm{~h}$ of incubation at all temperatures studied $\left(32-50{ }^{\circ} \mathrm{C}\right.$ ) (Figure 1 ). More pronounced $\mathrm{pH}$ shifts were observed in whey samples incubated within the range of $37-42{ }^{\circ} \mathrm{C}$. At this temperature range, $\mathrm{pH}$ decreased to values around 4.0 after $24 \mathrm{~h}$ of incubation and $\mathrm{pH}$ values ranging from 3.3 to 3.5 after $120 \mathrm{~h}$ of fermentation. Similarly, the temperature had a significant effect on the lactic acid production, where the highest values were observed at the temperature range of $37-42{ }^{\circ} \mathrm{C}$ with 13-14 g/L after $120 \mathrm{~h}$ of fermentation (Figure 2). The results obtained in this study indicate that NAWF production under this temperature range $\left(37-42{ }^{\circ} \mathrm{C}\right)$ resulted in more efficient lactic acid production and represents an attractive option to standardize artisanal cheese-making processes when NAWF is used for milk coagulation. At higher temperatures $\left(45-50{ }^{\circ} \mathrm{C}\right)$, lactic acid production was lower $(3-5 \mathrm{~g} / \mathrm{L})$ and no significant increase $(p<0.05)$ was observed after $24 \mathrm{~h}$, indicating that spontaneous whey fermentation was affected by the high temperature, possibly due to the thermal and $\mathrm{pH}$ tolerance of the lactic acid-producer microbiota contained in whey. On the other hand, even when lactic acid production was lower (at $32{ }^{\circ} \mathrm{C}$ than $37-42{ }^{\circ} \mathrm{C}$ ), the lactic acid production always kept increasing 
during the incubation time until reaching values of $8 \mathrm{~g} / \mathrm{L}$ after $120 \mathrm{~h}$ of fermentation. Similar behavior was reported by Simanca et al. (2010) [20], who observed that the spontaneous fermentation of whey occurs more slowly at temperatures lower than $32{ }^{\circ} \mathrm{C}$. In a recent study, Klupsaite et al. (2017) [21] reported a lactic acid production of $5.3 \mathrm{~g} / \mathrm{L}$ after $48 \mathrm{~h}$ at $37^{\circ} \mathrm{C}$ using Lactobacillus bulgaricus for whey fermentation, which is similar to the value obtained in our experiment $(5.5 \mathrm{~g} / \mathrm{L})$ using the same fermentation conditions $\left(37^{\circ} \mathrm{C}, 48 \mathrm{~h}\right.$ ) but using the native whey microbiota (Figure 2$)$. However, they also reported that Lactobacillus bulgaricus increased the lactic acid production to $19.8 \mathrm{~g} / \mathrm{L}$ when whey permeate was used [21].

The type of microorganisms found in whey is relevant for lactic acid production. De Candia et al. (2007) [22] reported that natural whey starters presented variability in cells count, where thermophilic lactobacilli ranged from 2.7 to 7.7 log of colony forming unit (CFU)/mL, but mesophilic lactobacilli registered low counts from 1.2 to $3.3 \log \mathrm{CFU} / \mathrm{mL}$. In our study (data not shown), fresh whey had total plate counts (PCA media) of $5.29 \log \mathrm{CFU} / \mathrm{mL}$ and increased up to $7.38 \log \mathrm{CFU} / \mathrm{mL}$ after $60 \mathrm{~h}$ of fermentation (at $37-42^{\circ} \mathrm{C}$ ) to finally reach $5.122 \log \mathrm{CFU} / \mathrm{mL}$ after $120 \mathrm{~h}$. Similarly, the lactobacilli count (MRS media) was $4.86 \log \mathrm{CFU} / \mathrm{mL}$ in fresh whey, and increased to $7.63 \log \mathrm{CFU} / \mathrm{mL}$ after $60 \mathrm{~h}$ of fermentation (at $37-42{ }^{\circ} \mathrm{C}$ ) to finally reach $5.82 \log \mathrm{CFU} / \mathrm{mL}$ after $120 \mathrm{~h}$. On the other hand, Streptococcus (M17 media) increased from 5.08 to $7.0 \log \mathrm{CFU} / \mathrm{mL}$ after $120 \mathrm{~h}$ of fermentation (at $37-42{ }^{\circ} \mathrm{C}$ ); however, when fermentation occurred at $50{ }^{\circ} \mathrm{C}$, the counts reached values of $9.08 \log \mathrm{CFU} / \mathrm{mL}$ after $120 \mathrm{~h}$. According to Aldrete-Tapia et al. (2014) [23], Lactobacillus is the largest producer genus of lactic acid and is assumed to be one of the main microorganisms involved in the natural fermentation of whey.

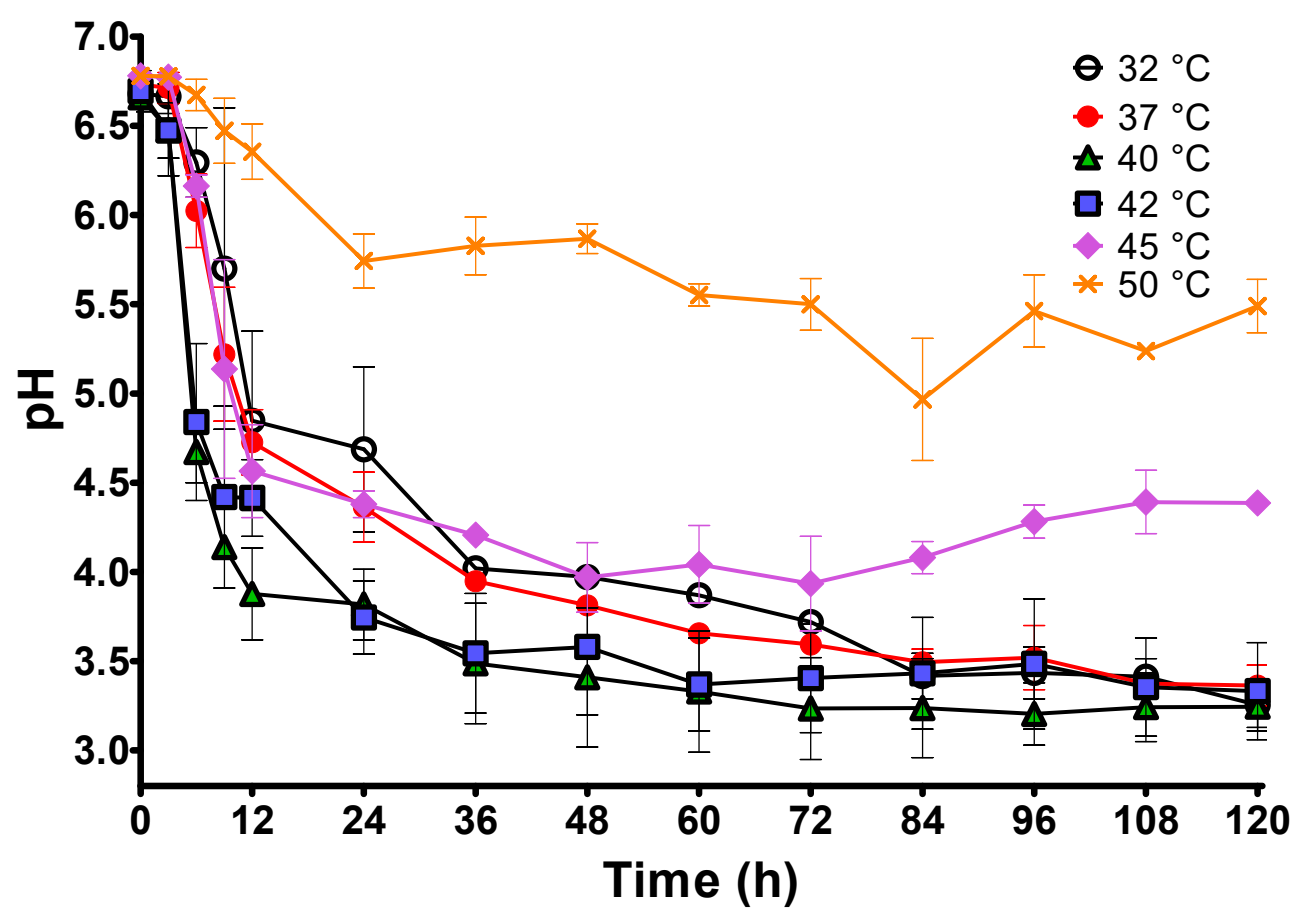

Figure 1. Temperature effect on $\mathrm{pH}$ during spontaneous fermentation of whey by its native microbiota. Values are expressed as mean $\pm \mathrm{SD}, n=6$. 


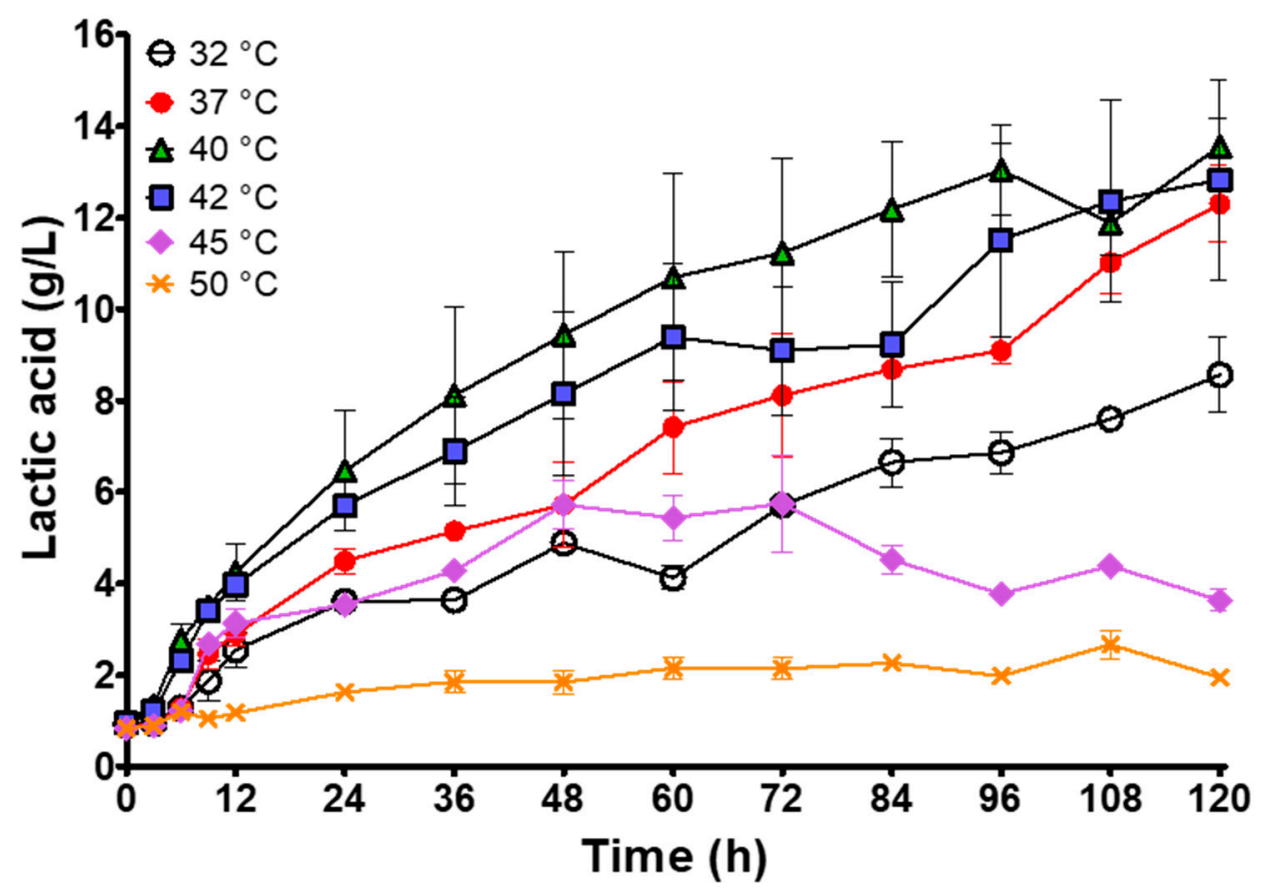

Figure 2. Temperature effect on the production of lactic acid $(\mathrm{g} / \mathrm{L})$ during spontaneous fermentation of whey by its native microbiota. Values are expressed as mean $\pm \mathrm{SD}, n=6$.

\subsection{Proteolysis Occurring during Spontaneous Whey Fermentation}

The temperature effect on proteolysis occurring during whey fermentation by the action of its native microbiota was evaluated by the content of free amino groups (Figure 3). The highest proteolysis occurred within the temperature interval of $37-45^{\circ} \mathrm{C}$, increasing from $36 \mu \mathrm{g} \mathrm{Gly} / \mathrm{mL}$ (fresh whey) to values in the range of 360-456 $\mathrm{gg}$ Gly/mL after $120 \mathrm{~h}$ of fermentation. Lower proteolysis occurred at temperatures of 32 and $50{ }^{\circ} \mathrm{C}$ ( 256 and $215.2 \mu \mathrm{g}$ Gly/mL after $120 \mathrm{~h}$ of fermentation, respectively). SDS-PAGE showed that whey protein hydrolysis occurred progressively during fermentation time at all incubation temperatures (Figure 4). A higher microbiota proteolytic activity occurred on bovine serum albumin (BSA) and IgG (heavy chain, IgGh) within the temperature range of $32-42{ }^{\circ} \mathrm{C}$. However, a lesser proteolytic effect on most proteins occurred at $50{ }^{\circ} \mathrm{C}$, which could be related to a temperature resistance of lactic acid bacteria naturally thriving in fresh whey. Lactic acid bacteria do not survive or develop at high temperatures, while thermophilic bacteria can resist but have less proteolytic activity [24]. In addition, the proteolytic action on whey proteins is dependent on the bacterial strain. Pescuma et al. (2012) [24] reported that L. acidophilus, L. bulgaricus, and L. casei presented more proteolytic activity than Str. thermophilus and $L b$. paracasei when reconstituted whey was fermented. They also reported that $\beta$-Lg and $\alpha$-La showed greater resistance to proteolytic degradation during whey fermentation at 37 and $42{ }^{\circ} \mathrm{C}$, as observed in this study. $\beta$-Lg is considered the milk protein with more resistance to the proteolytic action of several lactic acid bacteria strains [24,25]. 


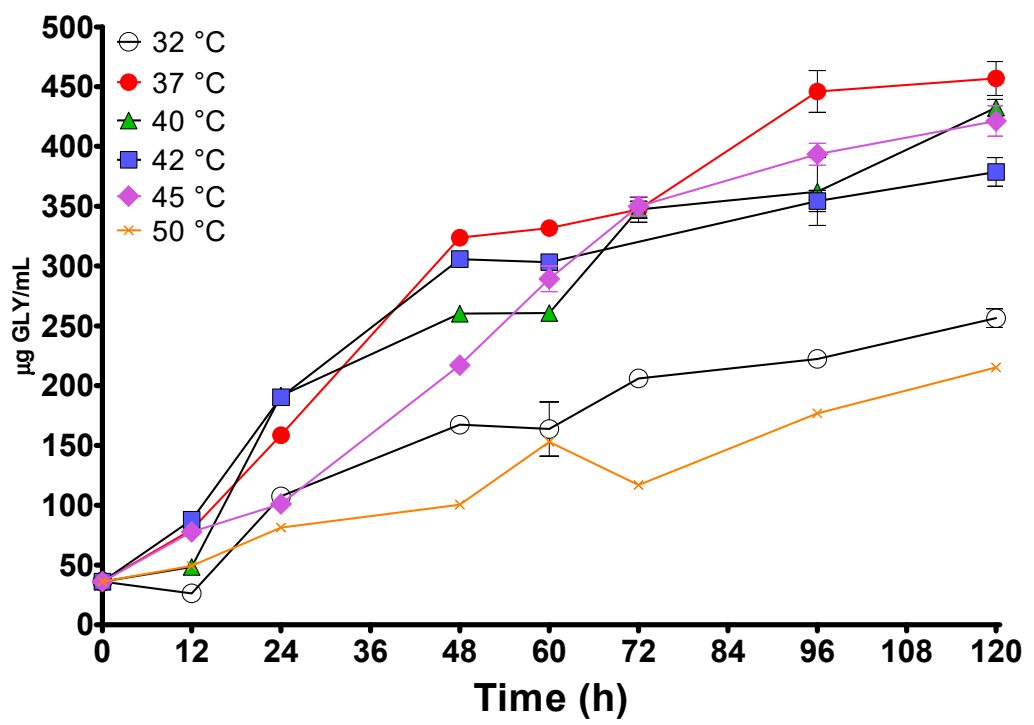

Figure 3. Temperature effect on proteolysis (free $\alpha$-amino) of whey during fermentation by its native microbiota. Values are expressed as mean $\pm \mathrm{SD}, n=4$.
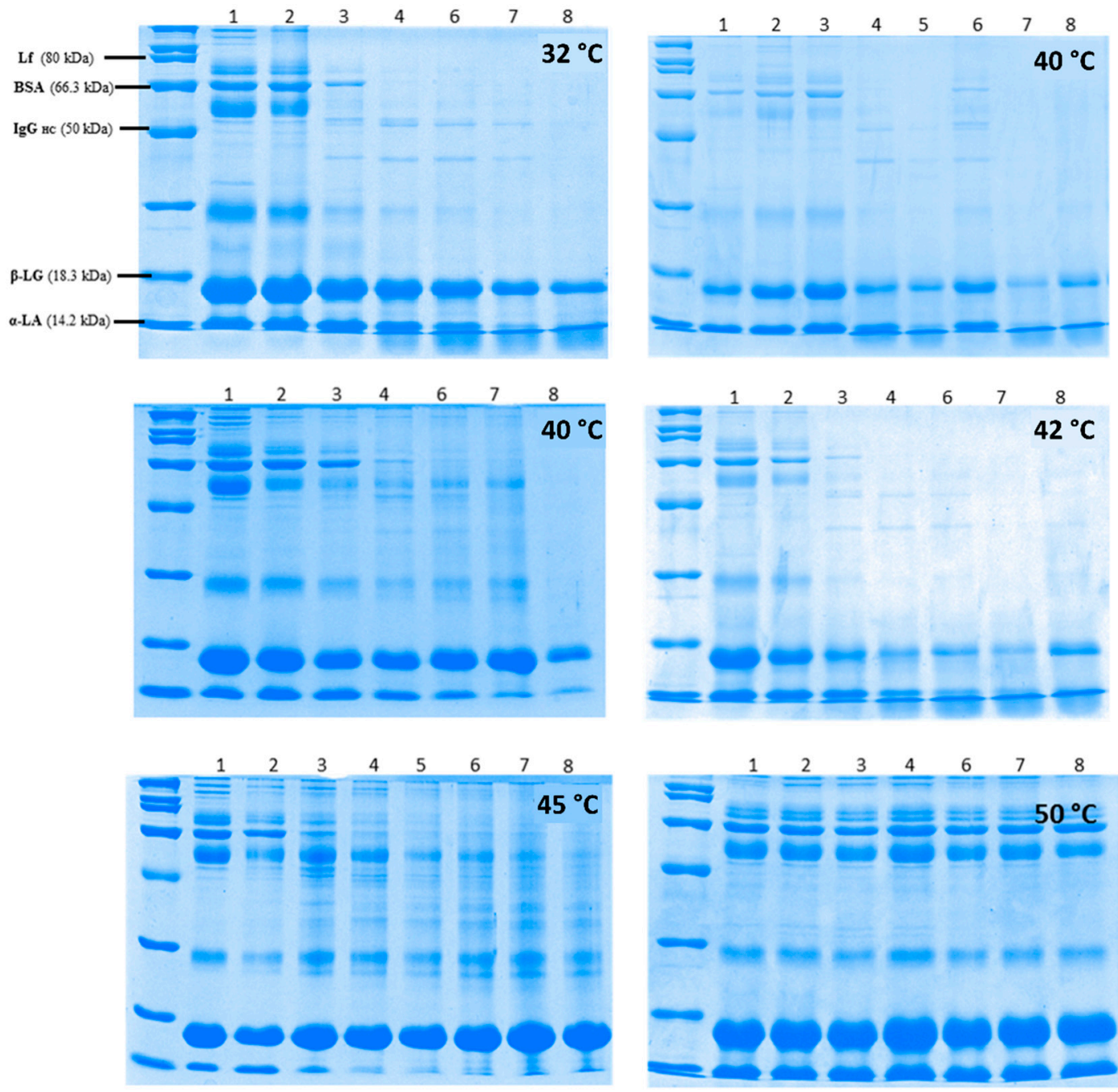

Figure 4. Electrophoretic (SDS-PAGE) protein profile of whey fermented by its native microbiota after $0,12,24,48,60,72,96$, and $120 \mathrm{~h}$ (lines $1-8$ respectively) at temperatures of $32,37,40,42,45$, and $50^{\circ} \mathrm{C}$. 
Fermented whey can also provide bioactive compounds including peptides, glutathione, antioxidants, immunoglobulins, enzymes, and probiotic microorganisms with a beneficial effect in health (e.g., digestion, immunity, and oxidative state). Several whey-derived valuable products can be obtained by microbial whey fermentation, which represent a niche of opportunities for the use of whey and its fractions in healthy-beverages formulations [26-29].

\subsection{ACE-Inhibitory Activity in Fermented Whey}

The microbiota of fresh whey have not been studied in detail; however, the presence of some species of lactic acid bacteria in whey can release bioactive peptides from whey proteins by their proteolytic action $[3,26]$. The percentage of ACE-inhibitory activity of peptide fractions $<10 \mathrm{kDa}$ of fermented whey obtained under different temperatures and fermentation time is shown in Figure 5. Fresh cheese whey (unfermented) registered 22\% ACE-I activity, a value that is in the range previously reported by other authors. Ibrahim et al. (2017) [30] reported a 20\% ACE-I for goat's milk whey, which is very similar to the values reported here for queso fresco whey, using unpasteurized (raw) cow milk for its production. A lower value (6-10\% ACE-I) has been reported for rehydrated whey powder [31,32]. ACE-inhibitory activity can vary according to whey origin, as well as the size of the peptide fraction evaluated [18]. In this study, the percentage of ACE-I increased with fermentation time at all temperatures evaluated (Figure 5). Almost all fermentation treatments (except at $50{ }^{\circ} \mathrm{C}$ ) reached values greater than $50 \%$ of ACE-I after 60 hours of fermentation. This increase was more evident in fermented whey obtained at temperatures in the range of $37-42{ }^{\circ} \mathrm{C}$, where values reached around $70 \%$ ACE-I after $120 \mathrm{~h}$ of fermentation. The maximum ACE-inhibitory activity could be related to the proteolytic activity of native bacteria in whey required to degrade whey proteins and release bioactive sequences.

Several in vitro and in vivo studies have reported the presence of antihypertensive peptides in fermented milk. Most studies are related to the inoculation of milk with different lactic acid bacteria strains to evaluate their performance in terms of the release of antihypertensive peptides from milk caseins $[10,33]$. Despite the health-promoting effects of whey and whey proteins, only a few studies have addressed the health benefits of fermented whey. Didelot et al. (2006) [34] prepared a caprine fermented whey by the inoculation of whey with the microbiota of 25 kinds of cheese and reported that only six of them presented ACE-I activity ranging from $31 \%$ to $51 \%$. Recently, a fermented probiotic dairy beverage produced with goat whey powder containing L. casei BGP93 and Str. thermophilus TA-40 exhibited ACE-inhibitory activity [32]. Studies on the presence of peptides with ACE-I activity in fermented whey are scarce; however, beneficial health effects other than antihypertensive properties have been reported. A fermented whey produced by its inoculation with traditional homemade Kazak yoghurt showed an anti-atherosclerotic effect in rabbits [35]. Fermented whey produced by the inoculation of whey with Lactobacillus plantarum DK211 (isolated from kimchi) showed an anti-obesity effect in rats [36], and when L. casei was used, the fermented whey showed hepatoprotective effects in chronic alcohol-induced mice [37].

Bioactive peptides sequences with antidiabetic, anticarcinogenic, antioxidant, antiobesogenic, and immunomodulant properties found in several protein sources have been produced by simulated digestion, fermentation, and enzymatic processes [8]. Milk proteins are recognized as an excellent source of bioactive peptides. In the same way, cheese whey has been recommended as an attractive protein source to produce functional whey beverages, especially as probiotics vehicles [25,38]. The ACE-inhibitory activity in whey fermented by its native microbiota detected in this trial indicates that proteolysis occurring during spontaneous whey fermentation releases bioactive peptides and represents an attractive strategy to produce whey-based beverages with potential health benefits. 

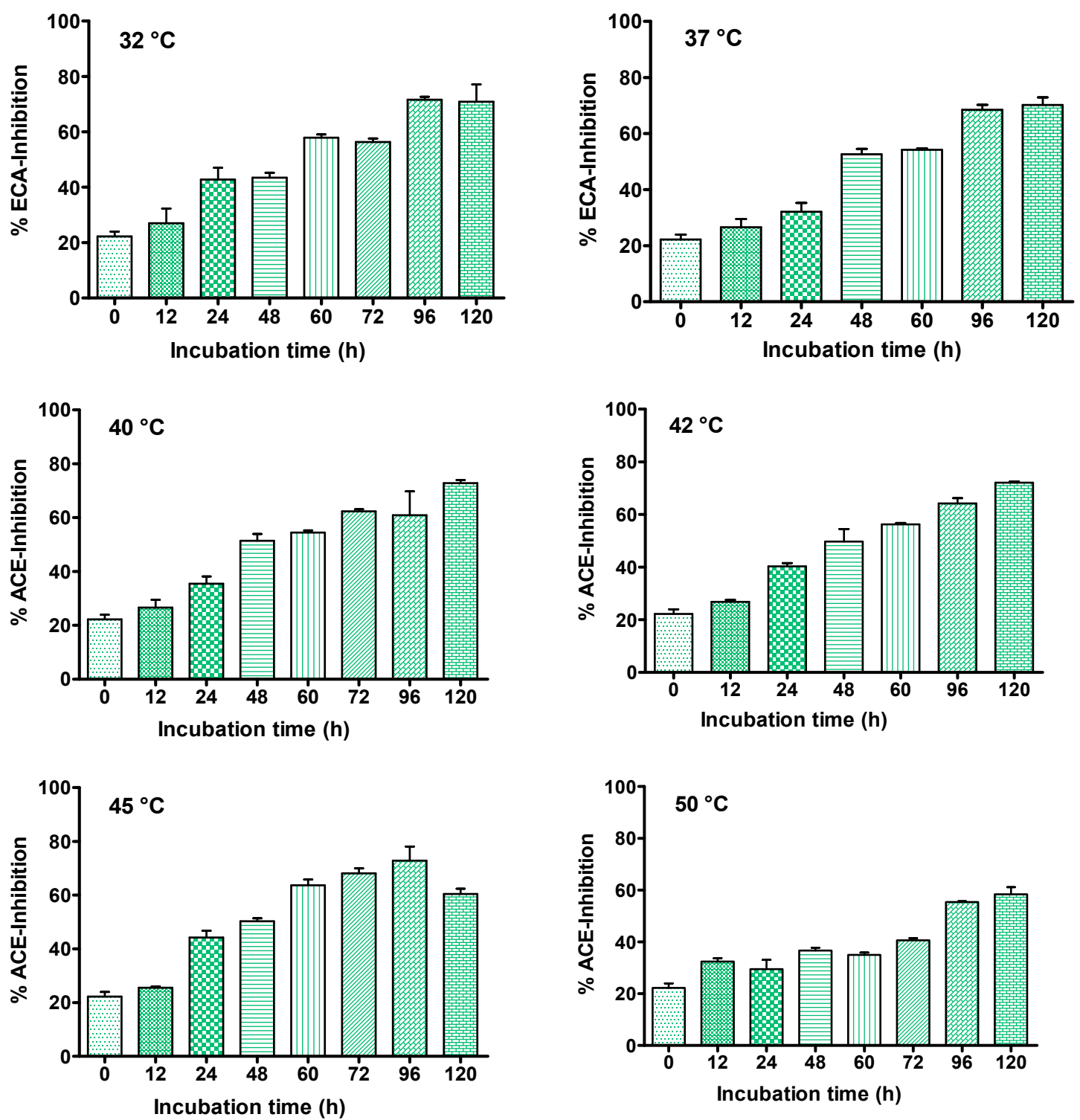

Figure 5. Effect of temperature on angiotensin-converting enzyme (ACE)-activity inhibition by peptide fractions $<10 \mathrm{kDa}$ during whey fermentation by its native microbiota. Values are mean $\pm \mathrm{SD}, n=4$.

\section{Conclusions}

Temperature affected the lactic acid production, proteolysis, and the release of bioactive peptides with ACE-inhibitory activity during the fermentation process of whey by its native microbiota. Peptide fractions with ACE-inhibitory activity in fermented whey indicate that endogenous bacterial proteolytic action can release bioactive peptide sequences from whey proteins. Therefore, the traditional cheese whey fermentation process using its native microbiota offers an attractive strategy to produce whey-based products with high nutritional value and additional health benefits, such as antihypertensive properties.

Author Contributions: Conceptualization: M.A.M.-M., A.F.G.-C., and B.V.-C.; Data curation: M.A.M.-M.; Formal analysis: G.R.R.-P., D.A.G.-V., and M.J.T.-L.; Funding acquisition: M.A.M.-M.; Investigation: G.R.R.-P., D.A.G.-V., and M.J.T.-L.; Methodology: G.R.R.-P. and C.O.G.-S.; Supervision: M.J.T.-L.; Visualization: B.V.-C.; Writing-review and editing: M.A.M.-M., M.M.-P., C.O.G.-S., A.F.G.-C., and B.V.-C. All authors have read and agreed to the published version of the manuscript.

Funding: This study was supported by the Mexican Council of Science and Technology (CONACYT; México, City, Mexico) research project Grant PDPCN2014-1 No. 248100. 
Acknowledgments: The authors express their gratitude to the Mexican Council of Science and Technology (CONACYT) for the scholarship granted to authors Glen R. Robles-Porchas and Daniel A. Gonzalez-Velazquez. Also, the authors would like to thank Anakaren Altamirano-Martinez and Wendy Mora-Cortes for their technical assistance.

Conflicts of Interest: The authors declare no conflict of interest. CONACYT had no role in the design of the study; in the collection, analyses, or interpretation of data; in the writing of the manuscript, or in the decision to publish the results.

\section{References}

1. El-Tanboly, E.S.; El-Hofi, M. Khorshid. Recovery of cheese whey, a by-product from the dairy industry for use as an animal feed. J. Nutr. Health Food Eng. 2017, 6, 148-154. [CrossRef]

2. Yadav, J.S.S.; Yan, S.; Pilli, S.; Kumar, L.; Tyagi, R.D.; Surampalli, R.Y. Cheese whey: A potential resource to transform into bioprotein, functional/nutritional proteins and bioactive peptides. Biotechnol. Adv. 2015, 33, 756-774. [CrossRef]

3. Mazorra-Manzano, M.A.; Moreno-Hernández, J.M. Properties and options for the valorization of whey from the artisanal cheese industry. CienciaUAT 2019, 14, 133-144.

4. McSweeney, P.L.H. Biochemistry of cheese ripening. Int. J. Dairy Technol. 2004, 57, 127-144. [CrossRef]

5. Hernández-Rojas, M.; Vélez-Ruíz, J.F. Suero de leche y su aplicación en la elaboración de alimentos funcionales. Temas Sel. Ing. Aliment. 2014, 8, 13-22.

6. Brandelli, A.; Daroit, D.J.; Corrêa, A.P.F. Whey as a source of peptides with remarkable biological activities. Food Res. Int. 2015, 73, 149-161. [CrossRef]

7. Cuevas-González, P.F.; Heredia-Castro, P.Y.; Méndez-Romero, J.I.; Hernández-Mendoza, A.; Reyes-Díaz, R.; Vallejo-Cordoba, B.; González-Córdova, A.F. Artisanal Sonoran cheese (Cocido cheese): An exploration of its production process, chemical composition and microbiological quality. J. Sci. Food Agric. 2017, 97, 4459-4466. [CrossRef]

8. Mazorra-Manzano, M.A.; Ramírez-Suarez, J.C.; Yada, R.Y. Plant proteases for bioactive peptides release: A review. Crit. Rev. Food Sci. Nutr. 2018, 58, 2147-2163. [CrossRef]

9. Hernández-Ledesma, B.; Contreras, M.M.; Recio, I. Antihypertensive peptides: Production, bioavailability and incorporation into foods. Adv. Colloid Interface Sci. 2011, 165, 23-35. [CrossRef]

10. Rodríguez-Figueroa, J.C.; González-Córdova, A.F.; Astiazaran-García, H.; Hernández-Mendoza, A.; Vallejo-Cordoba, B. Antihypertensive and hypolipidemic effect of milk fermented by specific Lactococcus lactis strains. J. Dairy Sci. 2013, 96, 4094-4099. [CrossRef]

11. Association of Official Analytical Chemists (AOAC). Official Methods of Analysis, 16th ed.; Association of Official Analytical Chemists: Washington, DC, USA, 2002.

12. Church, F.C.; Swisgood, H.E.; Porter, D.H.; Catignani, G.L. Spectrophotometric Assay Using o-Phthaldialdehyde for Determination of Proteolysis in Milk and Isolated Milk Proteins. J. Dairy Sci. 1983, 66, 1219-1227. [CrossRef]

13. Laemmli, U. Cleavage of structural proteins during the assembly of the head of bacteriophage T4. Nature 1970, 227, 680-685. [CrossRef]

14. Cushman, D.W.; Cheung, H.S. Spectrophotometric assay and properties of the angiotensin-converting enzyme of rabbit lung. Biochem. Pharmacol. 1971, 20, 1637-1648. [CrossRef]

15. Wu, J.; Aluko, R.E.; Muir, A.D. Improved method for direct high-performance liquid chromatography assay of angiotensin-converting enzyme-catalyzed reactions. J. Chromatogr. A 2002, 950, 125-130. [CrossRef]

16. Spalatelu, C. Biotechnological Valorisation of Whey. Innov. Rom. Food Biotechnol. 2012, 10, 1-8.

17. Blaschek, K.M.; Wendorff, W.L.; Rankin, S.A. Survey of Salty and Sweet Whey Composition from Various Cheese Plants in Wisconsin. J. Dairy Sci. 2007, 90, 2029-2034. [CrossRef]

18. Tarango-Hernández, S.; Alarcón-Rojo, A.D.; Robles-Sánchez, M.; Gutiérrez-Méndez, N.; Rodríguez-Figueroa, J.C. Short communication: Potential of Fresco-style cheese whey as a source of protein fractions with antioxidant and angiotensin-I-converting enzyme inhibitory activities. J. Dairy Sci. 2015, 98, 7635-7639. [CrossRef]

19. Panesar, P.S.; Kennedy, J.F.; Gandhi, D.N.; Bunko, K. Bioutilisation of whey for lactic acid production. Food Chem. 2007, 105, 1-14. [CrossRef] 
20. Simanca, M.; Arteaga, M.; Pérez, Y.; Soto, M.; Salcedo, J. Characterization and study of spontaneous fermentation offermented milk product (suero costeño) produced in Monteria. MVZ Córdoba 2010, 15, 1944-1953.

21. Klupsaite, D.; Juodeikiene, G.; Arbones, E.; Quintáns, A.P.; Zadeike, D.; Bartkiene, E.; Glasner, C.; Dikiy, A.; Shumilina, E. A Comparison Study on the Production and Recovery of Lactic Acid by Fermenting Dairy By-Products with P. acidilactici and Lb. delbrïeckii spp. bulgaricus. Waste Biomass Valoriz. 2019, 10, 1519-1528. [CrossRef]

22. De Candia, S.; De Angelis, M.; Dunlea, E.; Minervini, F.; McSweeney, P.L.H.; Faccia, M.; Gobbetti, M. Molecular identification and typing of natural whey starter cultures and microbiological and compositional properties of related traditional Mozzarella cheeses. Int. J. Food Microbiol. 2007, 119, 182-191. [CrossRef] [PubMed]

23. Aldrete-Tapia, A.; Escobar-Ramírez, M.C.; Tamplin, M.L.; Hernández-Iturriaga, M. High-throughput sequencing of microbial communities in Poro cheese, an artisanal Mexican cheese. Food Microbiol. 2014, 44, 136-141. [CrossRef] [PubMed]

24. Pescuma, M.; Hébert, E.M.; Bru, E.; de Valdez, G.F.; Mozzi, F. Diversity in growth and protein degradation by dairy relevant lactic acid bacteria species in reconstituted whey. J. Dairy Res. 2012, 79, 201-208. [CrossRef]

25. Pescuma, M.; Hébert, E.M.; Mozzi, F.; Font de Valdez, G. Whey fermentation by thermophilic lactic acid bacteria: Evolution of carbohydrates and protein content. Food Microbiol. 2008, 25, 442-451. [CrossRef]

26. Pessione, E.; Cirrincione, S. Bioactive Molecules Released in Food by Lactic Acid Bacteria: Encrypted Peptides and Biogenic Amines. Front. Microbiol. 2016, 7, 876. [CrossRef] [PubMed]

27. Pescuma, M.; Valdez, G.F.D.; Mozi, F. Whey-derived valuable products obtained by microbial fermentation. Appl. Microbiol. Biotechnol. 2015, 99, 6183-6196. [CrossRef] [PubMed]

28. Tsutsumi, R.; Tsutsumi, Y.M. Peptides and proteins in whey and their benefits for human health. Austin J. Nutr. Food Sci. 2014, 1, 1002.

29. Virtanen, T.; Pihlanto, A.; Akkanen, S.; Korhonen, H. Development of antioxidant activity in milk whey during fermentation with lactic acid bacteria. J. Appl. Microbiol. 2007, 102, 106-115. [CrossRef]

30. Ibrahim, H.R.; Ahmed, A.S.; Miyata, T. Novel angiotensin-converting enzyme inhibitory peptides from caseins and whey proteins of goat milk. J. Adv. Res. 2017, 8, 63-71. [CrossRef]

31. Mullally, M.M.; Meisel, H.; FitzGerald, R.J. Angiotensin-I-converting enzyme inhibitory activities of gastric and pancreatic proteinase digests of whey proteins. Int. Dairy J. 1997, 7, 299-303. [CrossRef]

32. Pereira, Á.M.D.S.; de Farias, D.R.B.; de Queiroz, B.B.; Nobre, M.S.D.C.; Cavalcanti, M.T.; Salles, H.O.; Dos Santos, K.M.O.; de Medeiros, A.C.D.; Florentino, E.R.; Alonso Buriti, F.C. Influence of a Co-culture of Streptococcus thermophilus and Lactobacillus casei on the Proteolysis and ACE-Inhibitory Activity of a Beverage Based on Reconstituted Goat Whey Powder. Probiot. Antimicrob. Proteins 2017, 11, 273-282. [CrossRef] [PubMed]

33. Beltrán-Barrientos, L.M.; Hernández-Mendoza, A.; Torres-Llanez, M.J.; González-Córdova, A.F.; Vallejo-Córdoba, B. Invited review: Fermented milk as antihypertensive functional food. J. Dairy Sci. 2016, 99, 4099-4110. [CrossRef] [PubMed]

34. Didelot, S.; Bordenave-Juchereau, S.; Rosenfeld, E.; Fruitier-Arnaudin, I.; Piot, J.-M.; Sannier, F. Preparation of angiotensin-I-converting enzyme inhibitory hydrolysates from unsupplemented caprine whey fermentation by various cheese microflora. Int. Dairy J. 2006, 16, 976-983. [CrossRef]

35. Nabi, X.-H.; Ma, C.-Y.; Manaer, T.; Heizati, M.; Wulazibieke, B.; Aierken, L. Anti-atherosclerotic effect of traditional fermented cheese whey in atherosclerotic rabbits and identification of probiotics. BMC Complement. Altern. Med. 2016, 16,1-13. [CrossRef]

36. Hong, S.-M.; Chung, E.-C.; Kim, C.-H. Anti-obesity Effect of Fermented Whey Beverage using Lactic Acid Bacteria in Diet-induced Obese Rats. Korean J. Food Sci. Anim. Resour. 2015, 35, 653-659. [CrossRef] 
37. Zhao, Z.W.; Pan, D.D.; Wu, Z.; Sun, Y.Y.; Guo, Y.X.; Zeng, X.Q. Antialcoholic liver activity of whey fermented by Lactobacillus casei isolated from koumiss. J. Dairy Sci. 2014, 97, 4062-4071. [CrossRef]

38. AbdulAlim, T.S.; Zayan, A.; Campelo, P.H.; Bakry, A.M. Development of new functional fermented product: Mulberry-whey beverage. J. Nutr. Food Res. Technol. 2018, 1, 64-69. [CrossRef] 